\title{
Functional differences between fish communities on artificial and natural reefs: a case study along the French Catalan coast
}

\author{
Barbara Koeck $^{1,2,3,7, *}$, Anne Tessier ${ }^{1,4}$, Anik Brind'Amour ${ }^{5}$, Jérémy Pastor ${ }^{1,2}$, \\ Benjamin Bijaoui ${ }^{1,2}$, Nicolas Dalias ${ }^{4}$, Patrick Astruch ${ }^{6}$, Gilles Saragoni ${ }^{1,2}$, \\ Philippe Lenfant ${ }^{1,2}$
}

\author{
${ }^{1}$ Univ. Perpignan Via Domitia, Centre de Formation et de Recherche sur les Environnements Méditerranéens, UMR 5110, \\ 66860 Perpignan, France \\ ${ }^{2}$ CNRS, Centre de Formation et de Recherche sur les Environnements Méditerranéens, UMR 5110, 66860 Perpignan, France \\ ${ }^{3}$ Ecole Pratique des Hautes Etudes, Univ. Perpignan Via Domitia, 66860 Perpignan, France \\ ${ }^{4}$ SEANEO, 66100 Perpignan, France \\ ${ }^{5}$ IFREMER Département Ecologie et Modèles pour l'Halieutique, 44311 Nantes Cedex 03, France \\ ${ }^{6}$ GIS Posidonie, Parc scientifique \& technologique de Luminy, 13288 Marseilles Cedex 09, France \\ ${ }^{7}$ Present address: Stella Mare 'Sustainable Technologies for LittoraL Aquaculture and MArine REsearch', \\ UMR 6134 Università di Corsica Pasquale Paoli / CNRS, Lieu-dit ‘U CASONE', 20620 Biguglia, Corsica, France
}

\begin{abstract}
In the context of growing anthropogenic disturbances that deeply alter marine coastal ecosystems, various management tools are used to protect biodiversity, such as fishing gear limitations, fishing quotas, protected areas or the creation of artificial reefs (ARs). In contrast to the other management tools, ARs require a modification of natural habitats. We used underwater visual censuses to investigate the effect of habitat modification on the structure of fish communities by comparing a natural reef (NR) to ARs with different habitat complexity. Different fish assemblage descriptors were used to assess species- and functional- and community-level aspects of the assemblages. ARs were rapidly colonized by adult fishes and presented community compositions different from that of the NR. Fish densities and functional richness were higher in the ARs than in the NR. Small isolated artificial structures, such as culverts and box-culverts, had different fish community compositions than more extended and complex structures, demonstrating the effect of structural habitat complexity on fish assemblages. Fish density was higher in small structures, most likely due to habitat isolation and patchiness. This study indicates that ARs which are located along sandy coastal areas with few rocky habitats and under high river nutrient influence are a suitable habitat for rocky coastal fish communities. Nevertheless, due to higher habitat complexity and lower fishing pressure on ARs, fish communities of an AR functionally differ from those of a NR. Further research is necessary to understand how these differences act on the properties of the ecosystem as well as on local fisheries.
\end{abstract}

KEY WORDS: Ecological niche · Fish community · Fisheries management · Functional diversity · Gulf of Lion · Habitat complexity $\cdot$ Mediterranean Sea $\cdot$ Underwater visual census

\section{INTRODUCTION}

World population growth and consumption habits have produced growing anthropogenic disturbances that have deeply altered ecosystems (Curran et al. 2002, Worm et al. 2006), notably marine ecosystems (Cole 2005), through pollution, habitat destruction, introduction of species, climate change and resource 
overexploitation. These disturbances are particularly concentrated along coastal areas, where more than $50 \%$ of the world's population lived at the turn of the century and more than $75 \%$ are expected to live by 2020 (Burke et al. 2001). Coastal areas provide many ecosystem goods and services, e.g. provisioning, regulating, cultural and supporting services (UNEP 2006). Despite previous efforts, coastal ecosystems are still considered threatened (Jackson 2008), and scientists and stakeholders are looking for effective management strategies. Artificial reefs (ARs) are one of the management tools currently employed, mainly (1) to offset marine resource declines and enhance fishing yields (Grossman et al. 1997, Jensen et al. 2000, Seaman \& Jensen 2000, Relini et al. 2008), particularly in the Mediterranean Sea (Baine \& Side 2003), but also (2) to restore damaged habitats (Pickering et al. 1999, Abelson 2006, Reed et al. 2006) and (3) mitigate the impact of wastewater (Antsulevich 1994, Leihonen et al. 1996) and aquaculture (Angel \& Spanier 2002, Tsemel et al. 2006, Gao et al. 2008). ARs modify the natural habitat and can directly impact coastal ecosystem processes.

ARs are widely used across the world's oceans (Brickhill et al. 2005) and have been studied for several decades, notably in temperate waters (Russell 1975, Burchmore et al. 1985, Anderson et al. 1989). In the Mediterranean Sea, the invertebrate and fish communities of some ARs have been monitored for up to $10 \mathrm{yr}$ (Relini et al. 2002, Nicoletti et al. 2007, Santos \& Monteiro 2007). Most of these studies have focused on the analysis of species diversity, density, abundance, biomass, catch per unit effort (CPUE), relative size and community composition to compare fish or invertebrate communities between artificial and natural habitats (Santos \& Monteiro 1998, Arena et al. 2007, Dupont 2008). Only some of these studies have included the functional attributes (e.g. vertical distribution) of fishes when comparing fish communities between ARs and natural habitats (e.g. Santos \& Monteiro 2007).

According to Hooper et al. (2005), the functional characteristics of species are an important component of biodiversity and ecosystem properties. Complementing traditional species diversity measures, functional diversity (FD) measures allow researchers to account for functional differences and niche complementarity among the species of a community (Tilman 2004), thus better reflecting the ecosystem properties. As the role occupied by many species within an ecosystem is rarely known, FD indices computed from the biological traits of species can be used as a proxy for how species interact with each other and their environment. Compared with the single investigation of taxonomic diversity, the study of functional trait-based metrics is particularly suited to the study of community responses to disturbances (Mouillot et al. 2013b). FD provides new insights into ecosystem functioning and has already been used to investigate communities in highly diverse ecosystems, such as coral reef fishes, alpine plants and tropical trees (Mouillot et al. 2013a).

The aim of this study was to determine if ARs function as a surrogate for natural reefs (NRs) We (1) compared fish assemblages of ARs with those of a natural rocky reef; (2) investigated interannual variability of fish assemblages during the first years of immersion of the monitored ARs; and (3) evaluated the effect of the complexity of AR habitat structures by comparing fish assemblages associated with 3 different AR types. As fish assemblage descriptors, we considered species diversity, FD, total density (ind. $\mathrm{m}^{-2}$ ) and relative community size structure and composition (weighted by density) to account for species-, functional- and community-level properties of fish assemblages. By investigating different levels of communities we aimed to improve our understanding of the ecological processes related to habitat modification and complexity which may assist in future management and conservation strategies.

\section{MATERIALS AND METHODS}

\section{Study site}

The AR system of Leucate-Le Barcarès was immersed in 2004 along the French Mediterranean coast in the Gulf of Lion, close to the Spanish border $\left(42^{\circ} 51^{\prime} \mathrm{N}, 3^{\circ} 03^{\prime} \mathrm{E}_{\text {; Fig. }}\right)$. Although the Mediterranean region is generally oligotrophic, the Gulf of Lion is a mesotrophic area due to nutrient inputs from the Rhône river (Bosc et al. 2004). The studied AR system consists of 6 reef groups located between the 15 and $30 \mathrm{~m}$ isobaths along a sandy coast (Fig. 1). Each of these reef groups consists of 28 reef sets of 3 different types (Fig. 2): isolated concrete boxes (B), isolated concrete culverts (C) and chaotic heap-type reefs $(\mathrm{H})$. The latter are composed of concrete slabs, beams and culverts as well as smaller elements such as shuttering blocks. The reef sets are $50 \mathrm{~m}$ apart, with a group occupying a total area of $400 \times 300 \mathrm{~m}$ (0.012 ha) (Koeck et al. 2011). The ARs are mainly surrounded by soft sediment bottoms. Cape Leucate, ca. $8 \mathrm{~km}$ north from the center of the studied AR system (Fig. 1), extends over $3 \mathrm{~km}$ of coastline and is 


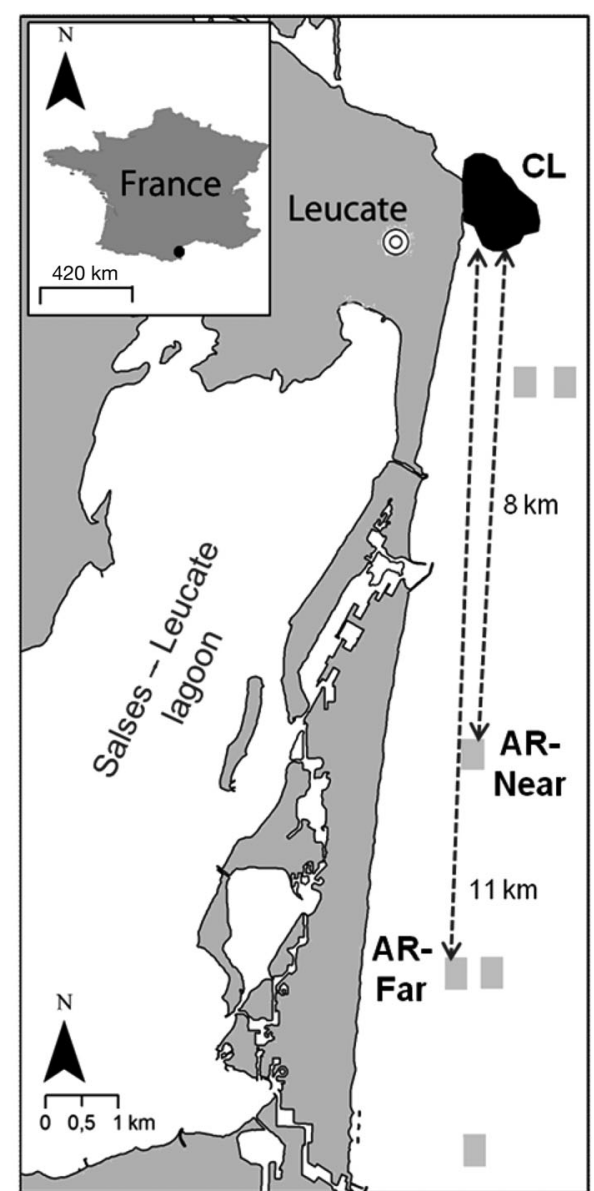

Fig. 1. Study area and sampling sites. Sampling was performed at the natural reef at Cape Leucate (CL) and at 2 artificial reef (AR) sites (AR-Near and AR-Far), named according to their distance from the natural reef

composed of rocky boulders and a rocky plateau reaching a maximum depth of $20 \mathrm{~m}$. Otherwise, the next closest extended rocky areas are located approximately $35 \mathrm{~km}$ south (Côte Vermeille) and approximately $55 \mathrm{~km}$ north (Cape Agde).

\section{Data sampling}

Underwater visual census

Sampling was conducted by SCUBA diving in the summer of 2006, 2007 and 2009 at 2 of the 6 AR groups and at Cape Leucate, the closest NR. These 3 locations presented similar depths of approximately $17 \mathrm{~m}$, with the nearest AR group (AR-Near) at a distance of $8 \mathrm{~km}$ from Cape Leucate and the farthest (AR-Far) located $11 \mathrm{~km}$ from Cape Leucate and $3 \mathrm{~km}$ from AR-Near (Fig. 1). The 3 different types of AR

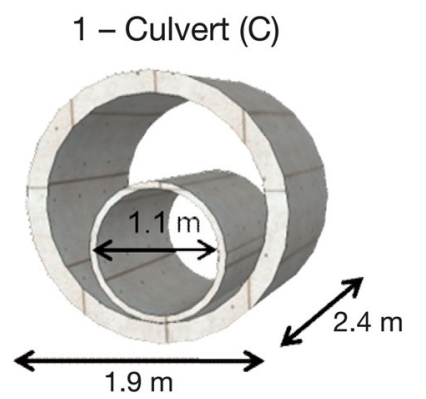

\section{2 - Box culvert (B)}
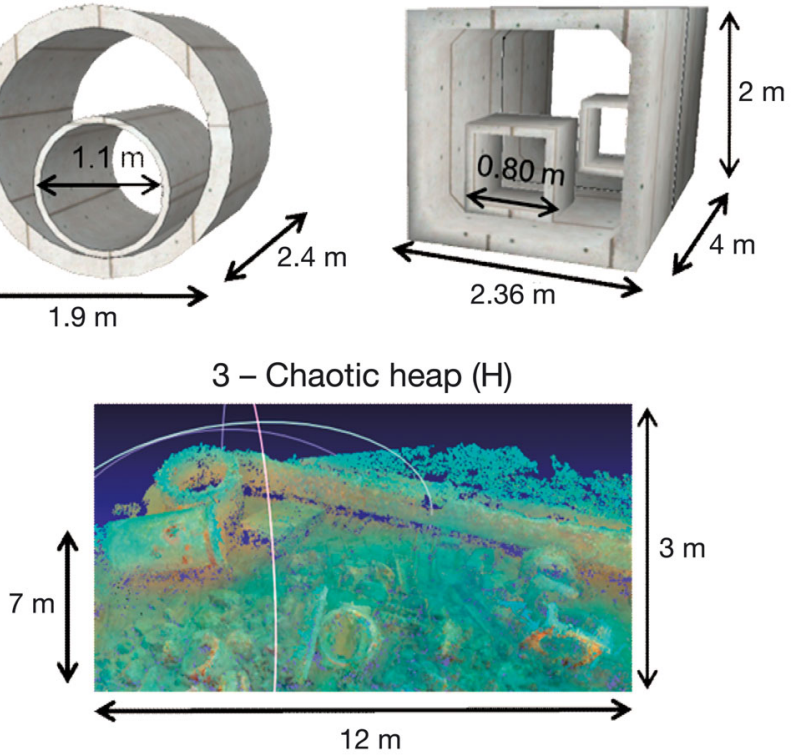

Fig. 2. Three-dimensional sketches and dimensions of the 3 different artificial reef (AR) habitat types comprising the Leucate-Le Barcarès ARs. The figure of the chaotic heaptype reef is taken from an image-based 3D reconstruction; the reef is composed of various elements of different sizes such as concrete slabs, beams and box culverts as well as smaller elements, such as shuttering blocks

sets were sampled from each AR group to account for the effect of habitat complexity on the fish communities. Sampling was skipped in 2008 due to bad weather conditions and low horizontal visibility close to the bottom, which introduced a bias in fish counts (Bozec et al. 2011). An underwater visual census (UVC) is a non-destructive monitoring technique that allows repeated observations of fish assemblages, and is thus a particularly well-suited method for monitoring fish colonization of ARs.

During the UVC, fish species were identified and counted, and individual relative size was estimated according to the following categories (HarmelinVivien \& Harmelin 1975): juvenile (young of the year), A1 small adults ( $<1 / 3$ of maximum total length; MTL), A2 medium adults (1/3 to $2 / 3$ of MTL) and A3 large adults ( $>2 / 3$ of MTL). At the NR, 3 randomly selected transects of $40 \times 2 \mathrm{~m}\left(80 \mathrm{~m}^{2}\right)$ were created according to the census methods described in Harmelin-Vivien et al. (1985). In 2009, only 2 replicates were performed on the NR due to high water turbidity. For the ARs, the visual census method was the same, except that, given the specific design of the AR structures, a complete inventory of the different AR types was performed. Thus, a visual census was performed on 3 randomly selected reef sets of each 
AR habitat type ( $\mathrm{B}, \mathrm{C}$ and $\mathrm{H}$ ) and for each location (AR-Near and AR-Far). The census surfaces and sampling efforts for the NRs and ARs are presented in Table 1. The census length of the NR was chosen to have approximately the same sampling surface as that of the largest AR type $(\mathrm{H})$, with a standardized census time of $35 \mathrm{~min}$.

\section{Species functional groups}

An a priori selection of functional traits was made based on the literature for the FD calculation. When data were missing, information was completed with FishBase (Froese \& Pauly 2012). Fish species were categorized according to 4 qualitative functional traits based on the literature (Tables $2 \& 3$ ). Feeding habits, vertical distribution and substrate preferences were chosen as they are functionally relevant and used in most FD analyses of marine fishes (Brind'Amour et al. 2009, Vinagre et al. 2011). Daily movement range was added to the species-trait matrix because it is a relevant trait in the context of the colonization of ARs and NRs of different architectural complexity. The attributes of a given trait were considered to be exclusive (i.e. for a given trait, only 1 attribute is possible per species).

\section{Data analysis}

\section{Species diversity indices}

To account for the bias induced by notoriously cryptic fish species (Willis 2001), Blennidae and Gobidae were removed from the analyses. Although cryptic species represent an important component of reef food webs, and occasionally of local fish diversity and reef productivity (Ackerman \& Bellwood 2002, Depczynski \& Bellwood 2003), UVC counts underestimate the diversity and density of cryptic species by up to $91 \%$ (Willis 2001). To account for cryptic species diversity and density, a high replicate survey (MacNeil et al. 2008) and extra transects solely dedicated to counting these species would have been necessary. Margalef's species diversity index $d_{\mathrm{Mf}}$ (Margalef 1958) and Pielou's evenness index $J^{\prime}$ (Pielou 1966) were calculated for each sample. Margalef's index was chosen because it attempts to compensate for unequal sample size (i.e. the different sampling surfaces of the different ARs and the NR). Nevertheless, direct comparisons of species diversity must be made with caution due to the asym-
Table 1. Sampling design. The number of samples corresponds to the 3 sampled years (2006, 2007 and 2009) combined with 3 samples per year, except for the natural reef where only 2 samples were made in 2009

\begin{tabular}{|lllrr|}
\hline $\begin{array}{l}\text { Reef } \\
\text { type }\end{array}$ & Location & Habitat type & Samples & $\begin{array}{c}\text { Surface } \\
\left(\mathrm{m}^{2}\right)\end{array}$ \\
\hline Artificial & AR-Near & Box culvert (B) & 9 & 9.44 \\
& & Culvert (C) & 9 & 4.56 \\
& & Chaotic heap (H) & 9 & 84.00 \\
Artificial & \multirow{2}{*}{ AR-Far } & Box culvert (B) & 9 & 9.44 \\
& & Culvert (C) & 9 & 4.56 \\
Natural & \multirow{2}{*}{ CL } & Chaotic heap (H) & 9 & 84.00 \\
& & Rocky boulders (NR) & 8 & 80.00 \\
\hline
\end{tabular}

Table 2. Categories for the 4 selected functional guilds

\begin{tabular}{|c|c|c|}
\hline $\begin{array}{l}\text { Functional } \\
\text { trait }\end{array}$ & Code & Definition \\
\hline \multirow[t]{5}{*}{ Feeding } & $\mathrm{H}$ & Herbivorous fish \\
\hline & Ov & $\begin{array}{l}\text { Omnivores with a preference } \\
\text { for vegetable material }\end{array}$ \\
\hline & Oa & $\begin{array}{l}\text { Omnivores with a preference } \\
\text { for animal material }\end{array}$ \\
\hline & $\mathrm{Cd}$ & $\begin{array}{l}\text { Carnivores with a preference } \\
\text { for decapodes and fish }\end{array}$ \\
\hline & $\mathrm{Cf}$ & $\begin{array}{l}\text { Carnivores with a preference for } \\
\text { fish and cephalopods }\end{array}$ \\
\hline \multirow[t]{3}{*}{$\begin{array}{l}\text { Vertical } \\
\text { distribution }\end{array}$} & $\mathrm{B}$ & $\begin{array}{l}\text { Benthic fish, living in or on } \\
\text { the substratum }\end{array}$ \\
\hline & $\mathrm{D}$ & $\begin{array}{l}\text { Demersal fish, living in the water } \\
\text { column near the bottom }\end{array}$ \\
\hline & $\mathrm{P}$ & $\begin{array}{l}\text { Pelagic fish, living in the water } \\
\text { column }\end{array}$ \\
\hline \multirow[t]{4}{*}{$\begin{array}{l}\text { Substratum } \\
\text { preference }\end{array}$} & $\mathrm{R}$ & $\begin{array}{l}\text { Rocky substratum / coralligenous } \\
\text { substratum }\end{array}$ \\
\hline & V & Vegetated substrate (seaweeds) \\
\hline & $\mathrm{S}$ & Soft substrate (mud, sand, pebble) \\
\hline & $\mathrm{N}$ & No substrate preference \\
\hline \multirow{4}{*}{$\begin{array}{l}\text { Daily move- } \\
\text { ment range }\end{array}$} & $\mathrm{F}$ & Fine scale $(<1 \mathrm{~m})$ \\
\hline & $\mathrm{L}$ & Local scale $(<100 \mathrm{~m})$ \\
\hline & $\mathrm{R}$ & Regional (<1 km) \\
\hline & B & Broad scale (>1 km) \\
\hline
\end{tabular}

metrical sampling design. Sample- and individualbased species accumulation curves (Chao 1 estimates) were computed using EstimateS software (Colwell 2006).

Functional diversity indices

Two aspects of FD, functional richness and evenness, were assessed to study the functional differences of fish communities. These 2 indices were com- 
Table 3. Species-traits matrix of fishes present at the artificial (AR-Near, ARFar) and natural reef (NR) locations. AR corresponds to AR-Near and AR-Far pooled together. Fee $=$ feeding habits; VertD $=$ vertical distribution; SubP $=$ substrate preference; DMR = daily movement range. Missing data was completed with FishBase (Froese \& Pauly 2012). See Table 2 for functional codes

\begin{tabular}{|c|c|c|c|c|c|c|c|c|c|}
\hline Species & NR & $\mathrm{AR}$ & $\begin{array}{l}\text { AR- } \\
\text { Near }\end{array}$ & $\begin{array}{l}\text { AR- } \\
\text { Far }\end{array}$ & Fee & VertD & SubP & DMR & Source \\
\hline Boops boops & & $x$ & $x$ & $x$ & $\mathrm{Ov}$ & $\mathrm{D}$ & $\mathrm{N}$ & $\mathrm{R}$ & $\mathrm{a}, \mathrm{b}, \mathrm{c}$ \\
\hline Chromis chromis & $x$ & $x$ & $x$ & & $\mathrm{Oa}$ & $\mathrm{D}$ & $\mathrm{R}$ & $\mathrm{L}$ & $a, b, c$ \\
\hline Conger conger & $x$ & $x$ & $x$ & $x$ & $\mathrm{Cf}$ & $\mathrm{B}$ & $\mathrm{R}$ & $\mathrm{L}$ & $\mathrm{a}, \mathrm{c}, \mathrm{d}$ \\
\hline Coris julis & $x$ & $x$ & & $x$ & $\mathrm{Oa}$ & $\mathrm{D}$ & $\mathrm{R}$ & $\mathrm{L}$ & $\mathrm{b}, \mathrm{c}, \mathrm{e}$ \\
\hline Ctenolabrus rupestris & $x$ & $x$ & $x$ & $x$ & $\mathrm{Oa}$ & $\mathrm{D}$ & $\mathrm{R}$ & $\mathrm{L}$ & c \\
\hline Dicentrarchus labrax & & $x$ & $x$ & $x$ & $\mathrm{Cd}$ & $\mathrm{D}$ & $\mathrm{N}$ & $\mathrm{B}$ & $\mathrm{f}, \mathrm{d}$ \\
\hline Diplodus annularis & & $x$ & $\times$ & $x$ & $\mathrm{Oa}$ & $\mathrm{D}$ & V & $\mathrm{L}$ & $\mathrm{c}, \mathrm{g}, \mathrm{h}$ \\
\hline Diplodus cervinus & $x$ & & & & Oa & $\mathrm{D}$ & $\mathrm{R}$ & $\mathrm{R}$ & $\mathrm{b}, \mathrm{i}$ \\
\hline Diplodus sargus & $x$ & $x$ & $x$ & $x$ & $\mathrm{Oa}$ & $\mathrm{D}$ & $\mathrm{R}$ & $\mathrm{R}$ & $\mathrm{b}, \mathrm{c}, \mathrm{j}, \mathrm{k}, \mathrm{l}$ \\
\hline Diplodus vulgaris & $x$ & $x$ & $x$ & $x$ & $\mathrm{Oa}$ & $\mathrm{D}$ & $\mathrm{R}$ & $\mathrm{R}$ & $\mathrm{b}, \mathrm{c}, \mathrm{j}, \mathrm{m}$ \\
\hline Mullus barbatus & $x$ & $x$ & $x$ & $x$ & Oa & B & S & $\mathrm{R}$ & $\mathrm{a}, \mathrm{b}, \mathrm{c}, \mathrm{n}$ \\
\hline Oblada melanura & & $x$ & $x$ & $x$ & $\mathrm{Oa}$ & $\mathrm{D}$ & $\mathrm{R}$ & $\mathrm{R}$ & $a, b, c$ \\
\hline Pagellus acarne & & $x$ & $x$ & & $\mathrm{Oa}$ & $\mathrm{D}$ & $\mathrm{S}$ & $\mathrm{R}$ & $\mathrm{b}, \mathrm{c}$ \\
\hline Pagellus erythrinus & & $x$ & & $x$ & $\mathrm{Oa}$ & $\mathrm{D}$ & $\mathrm{S}$ & $\mathrm{R}$ & c \\
\hline Phycis phycis & & $x$ & $x$ & $x$ & $\mathrm{Cf}$ & $\mathrm{B}$ & $\mathrm{R}$ & $\mathrm{L}$ & $\mathrm{o}, \mathrm{a}, \mathrm{c}$ \\
\hline Pomadasys incisus & & $x$ & $x$ & $x$ & $\mathrm{Oa}$ & $\mathrm{D}$ & $\mathrm{R}$ & $\mathrm{R}$ & $\mathrm{p}, \mathrm{q}$ \\
\hline Sarpa salpa & & $x$ & $x$ & & $\mathrm{H}$ & $\mathrm{D}$ & $\mathrm{V}$ & $\mathrm{R}$ & $\mathrm{b}, \mathrm{r}, \mathrm{c}, \mathrm{s}, \mathrm{t}$ \\
\hline Sciaena umbra & & $x$ & & $\times$ & $\mathrm{Cd}$ & $\mathrm{D}$ & $\mathrm{R}$ & $\mathrm{L}$ & $\mathrm{a}, \mathrm{b}, \mathrm{c}, \mathrm{u}, \mathrm{v}$ \\
\hline Scorpaena notata & & $x$ & $x$ & $\times$ & $\mathrm{Oa}$ & $\mathrm{B}$ & $\mathrm{R}$ & $\mathrm{F}$ & $\mathrm{a}, \mathrm{c}, \mathrm{w}$ \\
\hline Scorpaena porcus & $x$ & $x$ & $x$ & $x$ & $\mathrm{Cd}$ & $\mathrm{B}$ & $\mathrm{R}$ & $\mathrm{F}$ & $\mathrm{a}, \mathrm{b}, \mathrm{c}, \mathrm{x}$ \\
\hline Serranus cabrilla & $x$ & $x$ & $x$ & $x$ & $\mathrm{Oa}$ & $\mathrm{D}$ & $\mathrm{R}$ & $\mathrm{F}$ & $\mathrm{b}, \mathrm{c}, \mathrm{y}$ \\
\hline Serranus hepatus & $x$ & $x$ & & $x$ & Oa & $\mathrm{D}$ & $\mathrm{S}$ & $\mathrm{L}$ & $\mathrm{z}, \mathrm{c}$ \\
\hline Sparus aurata & & $x$ & $\times$ & & $\mathrm{Oa}$ & $\mathrm{D}$ & $\mathrm{N}$ & $\mathrm{R}$ & $c, x_{1}, \pm$ \\
\hline Spicara maena & & $x$ & & $x$ & $\mathrm{Oa}$ & $\mathrm{D}$ & V & $\mathrm{R}$ & $\mathrm{a}, \mathrm{c}$ \\
\hline Spicara smaris & & $\hat{x}$ & & $\hat{x}$ & $\mathrm{Oa}$ & $\mathrm{D}$ & $\mathrm{V}$ & $\mathrm{R}$ & $a_{1}, \mathrm{c}, \S$ \\
\hline $\begin{array}{l}\text { Spondyliosoma } \\
\text { cantharus }\end{array}$ & & $x$ & $x$ & $\times$ & Oa & $\mathrm{D}$ & $\mathrm{N}$ & $\mathrm{R}$ & $\mathrm{a}, \mathrm{c}$ \\
\hline $\begin{array}{l}\text { Symphodus } \\
\text { mediterraneus }\end{array}$ & $x$ & & & & $\mathrm{Oa}$ & $\mathrm{D}$ & $\mathrm{R}$ & $\mathrm{L}$ & $a, b, c$ \\
\hline $\begin{array}{l}\text { Symphodus } \\
\text { melanocercus }\end{array}$ & $x$ & & & & Oa & $\mathrm{D}$ & $\mathrm{V}$ & $\mathrm{L}$ & $\mathrm{a}, \mathrm{c}$ \\
\hline Trachurus trachurus & & $x$ & $x$ & $x$ & $\mathrm{Cd}$ & $P$ & $\mathrm{~N}$ & B & $\mathrm{b}, \mathrm{c}$ \\
\hline Trisopterus capelanus & $x$ & $x$ & $x$ & $x$ & $\mathrm{Oa}$ & $\mathrm{D}$ & $\mathrm{N}$ & $\mathrm{R}$ & 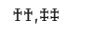 \\
\hline \multicolumn{4}{|c|}{$\begin{array}{l}\text { a Harmelin (1987), } \\
\text { b García-Charton \& Pérez-Ruzafa } \\
\quad(2001), \\
\text { c Stergiou \& Karpouzi (2001), } \\
{ }^{\mathrm{d}} \text { Pita \& Freire (2011), } \\
{ }^{\mathrm{e}} \text { Palmer et al. (2011), } \\
{ }^{\mathrm{f}} \text { Rogdakis et al. (2010), } \\
{ }^{\mathrm{g}} \text { Tzanatos et al. (2008), } \\
{ }^{\mathrm{h}} \text { March et al. (2011), } \\
{ }^{\mathrm{i}} \text { Derbal \& Kara (2006), } \\
{ }^{\mathrm{j}} \text { Abecasis et al. (2009), } \\
{ }^{\mathrm{k}} \mathrm{D}^{\prime} \text { Anna et al. (2011), } \\
{ }^{1} \text { Koeck et al. (2013), } \\
{ }^{\mathrm{m}} \text { Alós et al. (2012), } \\
{ }^{\mathrm{n}} \text { Machias et al. (1998), } \\
{ }^{\mathrm{o}} \text { Markle (1982), }\end{array}$} & \multicolumn{6}{|c|}{$\begin{array}{l}\text { p Chakroun-Marzouk \& Ktari (2006), } \\
\text { q Fehri-Bedoui \& Gharbi (2008), } \\
{ }^{\mathrm{r}} \text { Méndez-Villamil et al. (2001), } \\
{ }^{\mathrm{s}} \text { Jadot et al. (2006), } \\
{ }^{\mathrm{t}} \text { Abecasis et al. (2012), } \\
{ }^{\mathrm{u}} \text { La Mesa et al. (2008), } \\
{ }^{\mathrm{v}} \text { Alós \& Cabanellas-Reboredo (2012) } \\
{ }^{\mathrm{w}} \text { Scarcella et al. (2011b), } \\
{ }^{\mathrm{x}} \text { Scarcella et al. (2011a), } \\
{ }^{\mathrm{y}} \text { Alós et al. (2011), } \\
{ }^{\mathrm{z}} \text { Labropoulou et al. (1998), } \\
{ }^{\ddagger} \text { Chaoui et al. (2006), } \\
{ }^{\ddagger} \text { Abecasis \& Erzini (2008), } \\
\text { § Cetinic et al. (2011), } \\
{ }^{\ddagger} \text { Alonso-Fernández et al. (2008), } \\
{ }^{\ddagger} \text { Reubens et al. (2011), }\end{array}$} \\
\hline
\end{tabular}

cipal coordinate analysis (PCoA). The axes resulting from this PCoA were used as the new traits to compute the above-mentioned FD indices. From a geometrical point of view, the functional community trait space can be represented by 'a multidimensional space where the axes are functional traits along which species are placed according to their functional trait values' (Mouillot et al. 2013b, p. 167). Here, species and FD indices were chosen to be mathematically independent, and provide complementary information on the biodiversity of fish assemblages (Lyashevska \& Farnsworth 2012). Functional richness was assessed through the functional dispersion index (FDis) (Laliberté \& Legendre 2010), which corresponds to the mean distance of a 'species' to the centroid of the community in the community trait space. FDis accounts for not only the trait space filled by a community (convex hull volume), but also dispersion and species relative abundance. Functional evenness was assessed by FEve (Villéger et al. 2008), which calculates the number of species possessing a similar combination of functional traits weighted for abundance. In other words, FEve increases if abundance or functional distance (i.e. the distance between species inside the functional community trait space) is more evenly distributed among species. These multidimensional FD indices were calculated for each sample of the dataset using the GPL software R (R Development Core Team 2012) and the FD package (Laliberté \& Legendre 2010).

\section{Uni- and multivariate analyses}

The variability in total density, species diversity and evenness, functional dispersion and evenness and relative community size structure

puted using the same method. From the qualitative species-trait matrix, a Gower distance matrix was computed, which was then analyzed through a prin- were formally examined across years, reef types (AR vs. NR), locations (AR-Near, AR-Far, CL: Cap Leucate) and habitat type (ARs: B, C and H reefs; NR) 
with univariate PERMANOVA. An asymmetrical design was used, with all factors considered fixed. The 'Location' factor was considered nested in reef type ('Reef'), and the 'Habitat' factor nested in 'Location'. A similarity matrix based on the Euclidean distance of untransformed species and FD indices and the square-root transformed total density were generated for the analyses. For each term of the model, p-values were obtained with 9999 permutations of residuals under a reduced model and Type III sums of squares. Pair-wise tests were performed for the terms of the model where significant differences were revealed. When only a small number of permutations was possible, a Monte Carlo asymptotic pvalue was used instead of a permutation $p$-value (Anderson \& Robinson 2003).

Variability in the fish community composition (weighted by density) was also examined across years, locations and habitat type by a PERMANOVA performed on a Bray-Curtis similarity matrix, using the same design as for the univariate analysis. Densities were square-root transformed prior to data analysis. A significance threshold of 0.05 was used in both univariate and multivariate analyses. A similarity percentage analysis (SIMPER) was conducted to identify the contribution of each species to the community composition dissimilarities among reeftype and habitat type. For visualization of the multivariate patterns among habitat types, MDS plots based on the Bray-Curtis similarity matrix were generated. PERMANOVA, SIMPER analyses and MDS plots were conducted with the Primer software and the PERMANOVA add-on (Clarke \& Warwick 2001).

\section{RESULTS}

\section{Species diversity}

None of the species accumulation curves reached asymptotic levels of species richness in any of the habitat types (Fig. 3). A large variation in sampled individuals was noted among habitats, varying from 226 fishes for the NR to 3912 fishes for $\mathrm{H}$ at AR-Near (Fig. 3). On the sample-based species accumulation curves, the accumulation curves from the NR and different ARs were all grouped, and showed no differences in species richness among the natural and different AR habitats (Fig. 3). Species diversity was significantly different only among the artificial habitat types (Table 4) due to higher diversity at $\mathrm{H}$ than at $\mathrm{B}$ for AR-Near
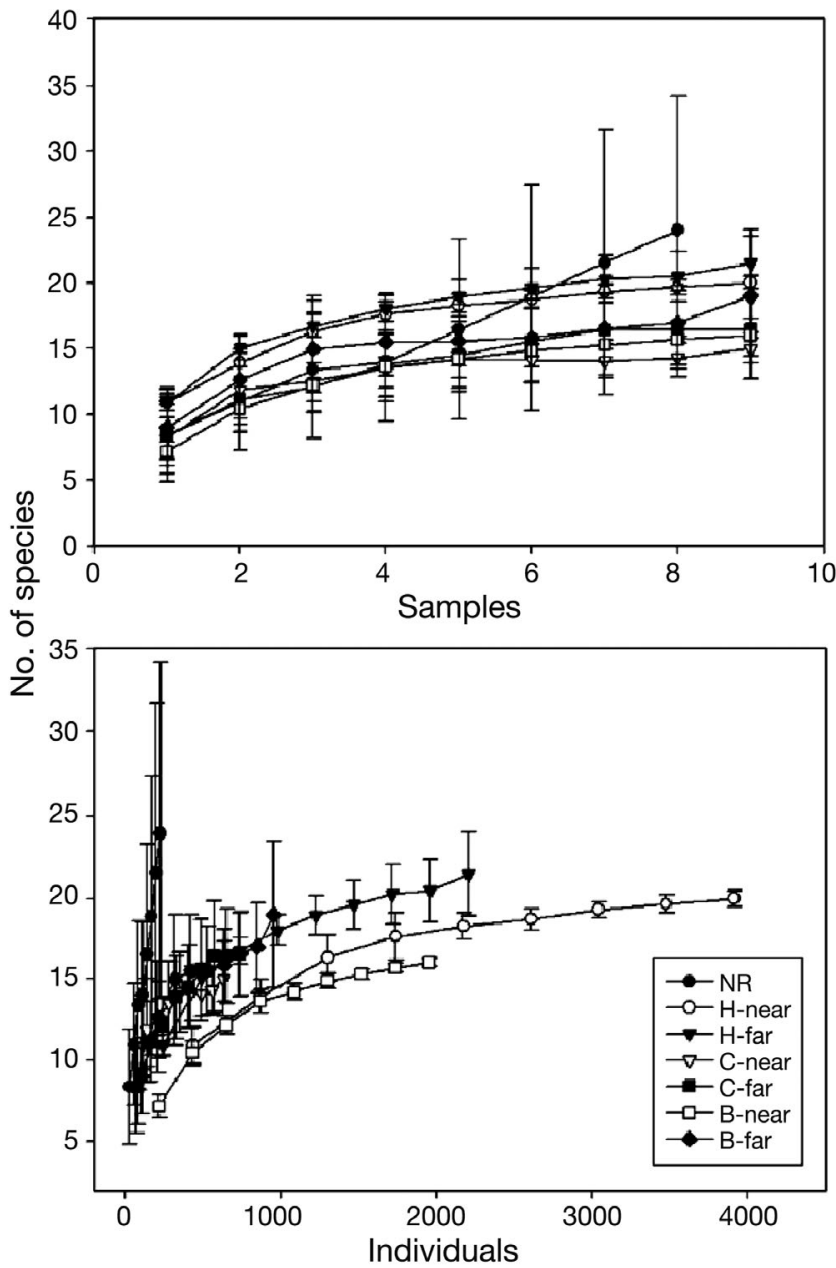

Fig. 3. Sample- and individual-based species accumulation curves (Chao 1 estimate) of the natural reef (NR) and the 3 different habitat structures (chaotic heaps $\mathrm{H}$, culvert reefs $\mathrm{C}$, box-culvert reefs B) of the 2 artificial reef locations (near and far). Dots represent the mean species richness and the errorbars the standard deviation

(Fig. 4). There were no differences in species diversity between the ARs and the NR (Table 4). Species evenness was significantly higher at the ARs $(0.21 \pm 0.19)$ than the NR $(0.03 \pm 0.03)$, and significantly higher at AR-Near than at AR-Far. Significant differences were also noted between the different artificial habitat types and locations in different years (Table 4). Pair-wise tests showed that evenness was significantly higher on $\mathrm{C}$ than on $\mathrm{H}$ for the AR-Near location, and that evenness was significantly higher in 2009 than in 2006 for the same location. For AR-Far, evenness was significantly higher in 2006 than in 2007 and 2009. No differences in evenness were observed between years for the NR location (Fig. 4). 
Table 4. Univariate 3-way PERMANOVA results for (a) Margalef's species diversity, (b) Pielou's species evenness, (c) functional dispersion, (d) functional evenness data and (e) density of fish communities. ${ }^{*} \mathrm{p}<0.1,{ }^{* *} \mathrm{p}<0.01,{ }^{* * *} \mathrm{p}<$ 0.001

\begin{tabular}{|c|c|c|c|c|}
\hline Source & $\mathrm{df}$ & MS & $F$ & $\mathrm{p}$ \\
\hline \multicolumn{5}{|l|}{ (a) Species diversity } \\
\hline Year & 2 & 0.3643 & 2.3967 & 0.0993 \\
\hline Reef & 1 & 0.0007 & 0.0046 & 0.939 \\
\hline Location (Reef) & 1 & 0.5529 & 3.6373 & 0.0617 \\
\hline Year $\times$ Reef & 2 & 0.295 & 1.9405 & 0.1634 \\
\hline Habitat (Location [Reef]) & 4 & 0.457 & 3.0068 & $0.0322^{*}$ \\
\hline Year $\times$ Location (Reef) & 2 & 0.2049 & 1.348 & 0.2776 \\
\hline Year $\times$ Habitat (Location [Reef]) & 8 & 0.2772 & 1.8237 & 0.0971 \\
\hline Residuals & 41 & 0.152 & & \\
\hline \multicolumn{5}{|l|}{ (b) Species evenness } \\
\hline Year & 2 & 0.0008 & 0.0424 & 0.9564 \\
\hline Reef & 1 & 0.2196 & 11.15 & $0.0013^{* *}$ \\
\hline Location (Reef) & 1 & 0.1443 & 7.324 & $0.0082^{* *}$ \\
\hline Year $\times$ Reef & 2 & 0.0049 & 0.2469 & 0.7744 \\
\hline Habitat (Location [Reef]) & 4 & 0.0671 & 3.4052 & $0.0189^{*}$ \\
\hline Year $\times$ Location (Reef) & 2 & 0.2517 & 12.778 & $0.0001^{* * *}$ \\
\hline Year $\times$ Habitat (Location [Reef]) & 8 & 0.0154 & 0.7807 & 0.6249 \\
\hline Residuals & 41 & 0.0197 & & \\
\hline \multicolumn{5}{|l|}{ (c) Functional dispersion } \\
\hline Year & 2 & 0.0002 & 0.0207 & 0.9788 \\
\hline Reef & 1 & 0.1512 & 15.645 & $0.0004^{* * *}$ \\
\hline Location (Reef) & 1 & 0.0534 & 5.5223 & $0.0247^{*}$ \\
\hline Year $\times$ Reef & 2 & 0.0057 & 0.5919 & 0.5621 \\
\hline Habitat (Location [Reef]) & 4 & 0.0058 & 0.6027 & 0.6729 \\
\hline Year $\times$ Location $($ Reef) & 2 & 0.005 & 0.514 & 0.5917 \\
\hline Year $\times$ Habitat (Location [Reef]) & 8 & 0.0045 & 0.4694 & 0.8726 \\
\hline Residuals & 41 & 0.0097 & & \\
\hline \multicolumn{5}{|l|}{ (d) Functional evenness } \\
\hline Year & 2 & 0.029 & 2.6341 & 0.0801 \\
\hline Reef & 1 & 0.0435 & 3.9576 & 0.0543 \\
\hline Location (Reef) & 1 & 0.0174 & 1.5854 & 0.2154 \\
\hline Year $\times$ Reef & 2 & 0.0441 & 4.0146 & $0.028 *$ \\
\hline Habitat (Location [Reef]) & 4 & 0.0078 & 0.7113 & 0.594 \\
\hline Year $\times$ Location $($ Reef) & 2 & 0.0228 & 2.0747 & 0.1359 \\
\hline Year $\times$ Habitat (Location $[$ Reef]) & 8 & 0.0456 & 4.1473 & $0.001^{* *}$ \\
\hline Residuals & 41 & 0.011 & & \\
\hline \multicolumn{5}{|l|}{ (e) Density (ind. $\mathrm{m}^{-2}$ ) } \\
\hline Year & 2 & 0.318 & 0.219 & 0.8064 \\
\hline Reef & 1 & 44.046 & 30.328 & $0.0001^{* * *}$ \\
\hline Location (Reef) & 1 & 4.6147 & 3.1775 & 0.0839 \\
\hline Year $\times$ Reef & 2 & 0.0549 & 0.0378 & 0.9632 \\
\hline Habitat (Location [Reef]) & 4 & 13.095 & 9.0166 & $0.0002^{* * *}$ \\
\hline Year $\times$ Location $($ Reef) & 2 & 1.7094 & 1.177 & 0.3226 \\
\hline Year $\times$ Habitat (Location [Reef]) & 8 & 2.7552 & 1.8972 & 0.0906 \\
\hline Residuals & 41 & 1.4523 & & \\
\hline
\end{tabular}

FEve was significantly different between reef types across years, and among habitat types across years (Table 4). Pair-wise tests showed that FEve was higher in $2006(0.57 \pm 0.13)$ than in $2007(0.48 \pm 0.08)$ and 2009 $(0.44 \pm 0.15)$ for the ARs only (Fig. 4) No differences were observed in FEve across years for the NR. Significant differences in FEve were observed for the B reefs of AR-Near (2006-2007: $t=4.9, \mathrm{p}=0.00 ; 2007-$ 2009: $t=3.0, \mathrm{p}=0.03$ ) and for the $\mathrm{C}$ reefs of AR-Far (2006-2007: $t=4.9$, $\mathrm{p}=0.00 ; 2007-2009$ : $t=3.8, \mathrm{p}=0.01$ ). In both cases, FEve was the highest in 2006 (AR-Near: $0.62 \pm 0.07$; AR-Far: $0.68 \pm 0.10$ ), followed by a sharp drop in 2007 (AR-Near: $0.38 \pm 0.05$; ARFar: $0.21 \pm 0.13$ ) and slight increase in 2009 (AR-Near: $0.49 \pm 0.04$; AR-Far: $0.53 \pm 0.06)$.

\section{Total density}

The PERMANOVA main tests showed that fish density was significantly different between reef types (Table 4), with higher densities at the ARs $\left(12.58 \pm 1.60\right.$ ind. $\left.\mathrm{m}^{-2}\right)$ than at the NR $\left(0.35 \pm 0.05\right.$ ind. $\left.\mathrm{m}^{-2}\right)$. Significant differences were also observed among the AR types, with lower fish densities at the $\mathrm{H}$ reefs than the $\mathrm{B}$ and $\mathrm{C}$ reefs (Fig. 4). No significant differences were observed among years, between locations (AR-Near, AR-Far and $\mathrm{CL}$ ) or for the interaction terms of the tested model (Table 4, Fig. 4).

\section{Relative fish size structure and community composition}

There were no differences in the relative size class ratios of the fish communities for any of the tested factors (Fig. 5, Table 5a). For all habitat types, medium-sized adults were predominant, except for the AR B reefs in 2006 and 2007, and the NR in 2009 (Fig. 5). The PERMANOVA main tests showed that fish community composition was significantly different among years, reef types and habitats
FDis was significantly different between reef types (Table 4), with higher values for the ARs (0.29 \pm 0.09$)$ than the NR $(0.14 \pm 0.05)$. FDis was also significantly different among the AR locations, with higher values at AR-Far $(0.33 \pm 0.08)$ than at AR-Near $(0.26 \pm 0.11)$. 


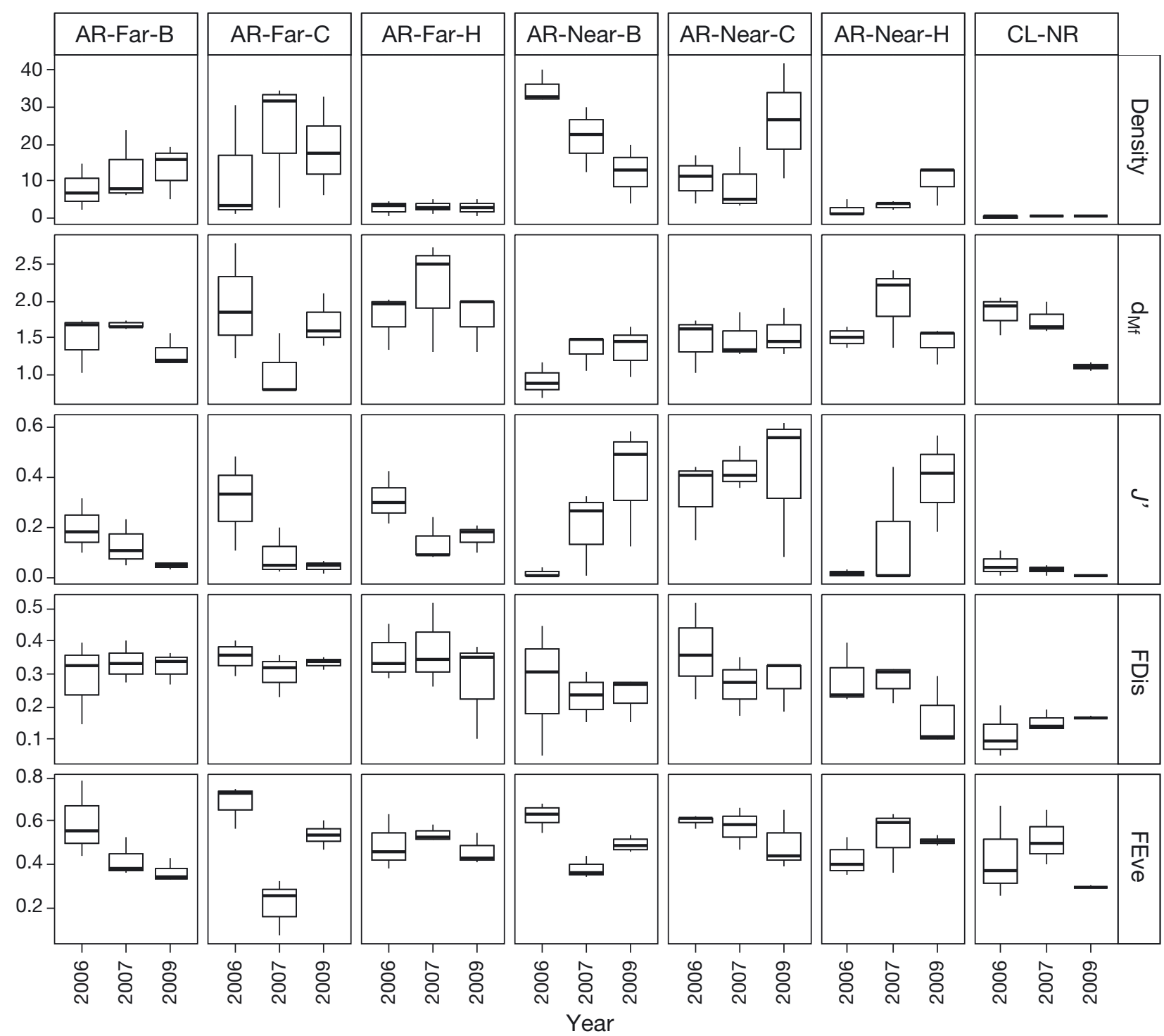

Fig. 4. Box-plots of density (ind. $\left.\mathrm{m}^{-2}\right)$, Margalefs' diversity $\left(\mathrm{d}_{\mathrm{Mf}}\right)$, Pielou's evenness $\left(\mathrm{J}^{\prime}\right)$, functional dispersion (FDis) and evenness (FEve) index of fish communities per location (AR-Near, AR-Far, CL), habitat type (B: box-culvert, C: culvert, H: chaotic heap type reef, NR: natural reef) and year. Box-plots represent the median, the first and third quartiles. Whiskers present the extreme values within the 1.5 inter-quartile range

and for reef types among years (Table $5 b)$. Community composition was different among all 3 years and between the ARs and the NR (Fig. 6). Pair-wise analysis of the effect of the interaction between years and reef type showed that community composition was different among the 3 years of the survey, but only for the ARs and not the NR. Pair-wise analysis of the effect of habitat highlighted that communities associated with $B$ and $C$ reefs were different from those associated with $\mathrm{H}$ reefs for both AR locations (AR-Near and AR-Far) (Fig. 6). SIMPER analysis indicated that bogue Boops boops Linnaeus, 1758, red mullet and surmullet Mullus sp. Linnaeus, 1758, horse mackerel Trachurus trachurus Linnaeus, 1758, white seabream Diplodus sargus Linnaeus, 1758, and common two-banded seabream Diplodus vulgaris Geoffroy Saint-Hilaire, 1817, were the primary contributors to the observed dissimilarity between reef types (80.19\%) and years (2006 vs. 2007: $69.53 \%$; 2006 vs. 2009 : $67 \%$; 2007 vs. 2009: $60.62 \%$ ), accounting for nearly $60 \%$ of the observed dissimilarity. The dissimilarity of fish communities among habitat types was mainly explained by these same fish species. Comber Serranus cabrilla Linnaeus, 1758, and Mediterranean rainbow wrasse Coris julis Linnaeus, 1758, also accounted for the dissimilarity of fish communi- 


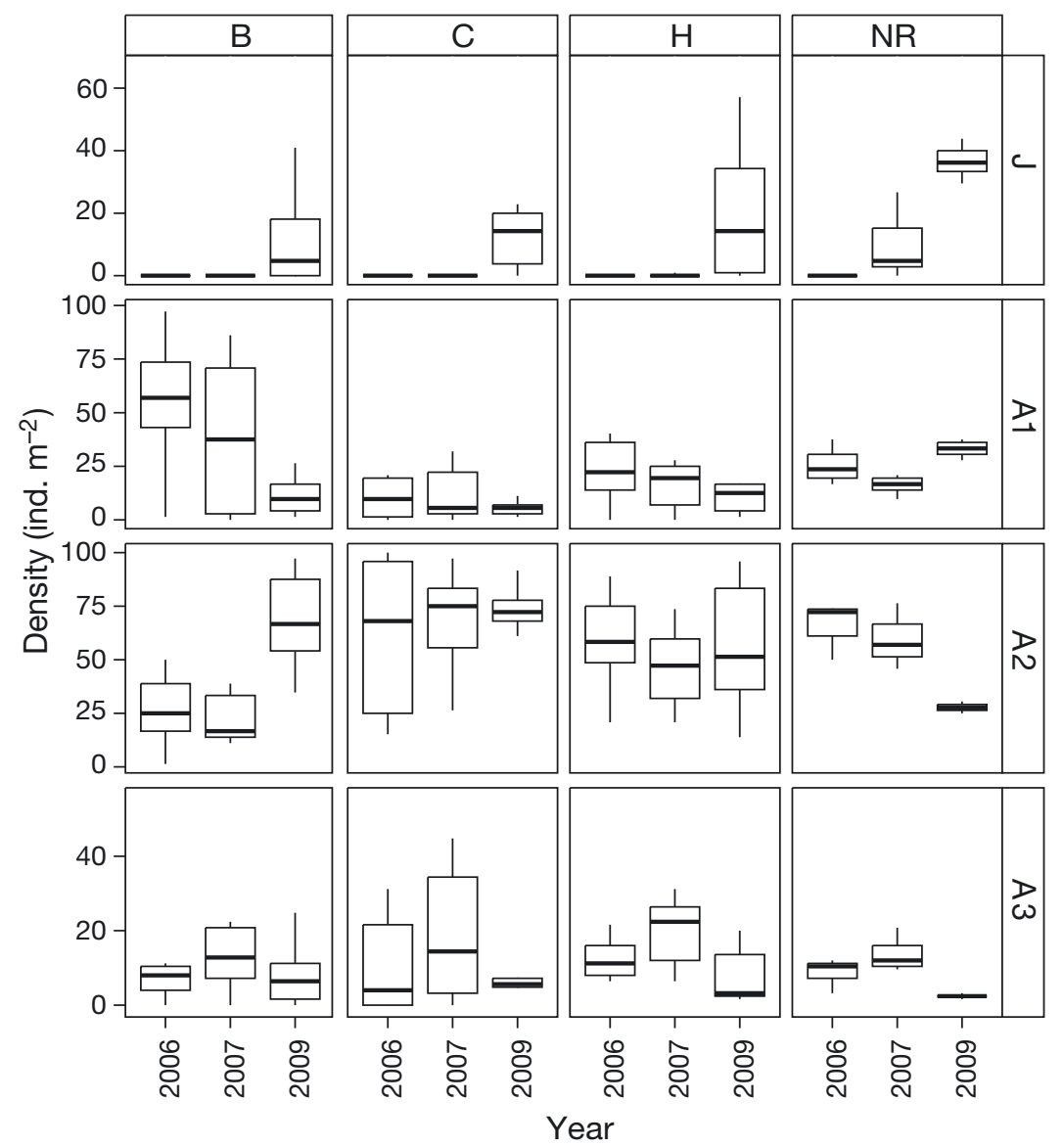

Fig. 5. Box-plots of fish density for each size class $(\mathrm{J}=$ juvenile, $\mathrm{A} 1=$ small adults, $\mathrm{A} 2=$ medium adults, $\mathrm{A} 3=$ large adults $)$ per habitat type $(\mathrm{B}=$ boxculvert, $\mathrm{C}=$ culvert, $\mathrm{H}=$ chaotic heap type reef, $\mathrm{NR}=$ natural reef) and year. Box-plots represent the median, the first and third quartiles. Whiskers present the extreme values within the 1.5 inter-quartile range

Table 5. (a) Univariate 3-way PERMANOVA for relative community size structure of total fish community and (b) multivariate 3-way PERMANOVA results for community composition. ${ }^{* * *} \mathrm{p}<0.001$

\begin{tabular}{|lcccc|}
\hline Source & df & MS & $F$ & $p$ \\
\hline (a) Community relative size structure & & & \\
Year & 2 & 1078.5 & 1.8257 & 0.1297 \\
Reef & 1 & 571.63 & 0.96767 & 0.3938 \\
Location (Reef) & 1 & 131.05 & 0.22184 & 0.8117 \\
Year $\times$ Reef & 2 & 630.5 & 1.0673 & 0.3675 \\
Habitat (Location [Reef]) & 4 & 794.57 & 1.3451 & 0.2382 \\
Year $\times$ Location (Reef) & 2 & 655.73 & 1.11 & 0.3729 \\
Year $\times$ Habitat (Location [Reef]) & 8 & 735.47 & 1.245 & 0.2565 \\
Residuals & 41 & 590.73 & & \\
(b) Community composition & & & & \\
Year & 2 & 4225.7 & 3.2320 & $0.0004^{* * *}$ \\
Reef & 1 & 22717.0 & 17.3750 & $0.0001^{* * *}$ \\
Location (Reef) & 1 & 1305.5 & 0.9985 & 0.4149 \\
Year $\times$ Reef & 2 & 3639.0 & 2.7832 & $0.0009^{* * *}$ \\
Habitat (Location [Reef]) & 4 & 5163.7 & 3.9494 & $0.0001^{* * *}$ \\
Year $\times$ Location (Reef) & 2 & 1357.1 & 1.0379 & 0.4063 \\
Year $\times$ Habitat (Location [Reef]) & 8 & 1460.9 & 1.1174 & 0.2767 \\
Residuals & 41 & 1307.5 & & \\
\hline
\end{tabular}

ties among habitat types, but to a smaller extent. The dissimilarity in fish community composition was $58.61 \%$ between $\mathrm{C}$ and B, 65.56\% between $\mathrm{C}$ and $\mathrm{H}, 62.84 \%$ between $\mathrm{B}$ and $\mathrm{H}, 83.88 \%$ between $\mathrm{C}$ and NR, $85.28 \%$ between $B$ and NR and $71.52 \%$ between $\mathrm{H}$ and NR. To ensure that the high contribution of the shoaling species $B$. boops did not mask any other pattern, univariate and multivariate multifactorial analyses were conducted again after the removal of this species from the communities (data not shown). The results confirmed the previously presented results obtained with the fish community including $B$. boops (same trends and magnitude).

\section{DISCUSSION}

\section{Contrasting fish communities between the ARs and the NR}

Fish assemblages of the Leucate-Le Barcarès ARs differed from those of the NR in density (AR > NR), species evenness (AR > NR), FDis (AR > NR) and community composition. Species diversity and FEve remained unaffected by reef type. Compared with the NR, nearly twice as many species were encountered on ARs. Despite this difference, there were no differences in species diversity between the 2 reef types. A wider sampling of the NR would be necessary for a better investigation of species richness in this area to verify whether the low number of species encountered was due to the low fish density of the NR or due to the habitat characteristics. The species accounting for the greatest dissimilarity between the ARs and the NR were either species present in both community types but at a much lower density at the NR (Mullus sp., Diplodus sargus, D. vulgaris), or species uniquely present at the ARs, such as the pelagic Trachurus trachurus and Boops boops. The high contribu- 


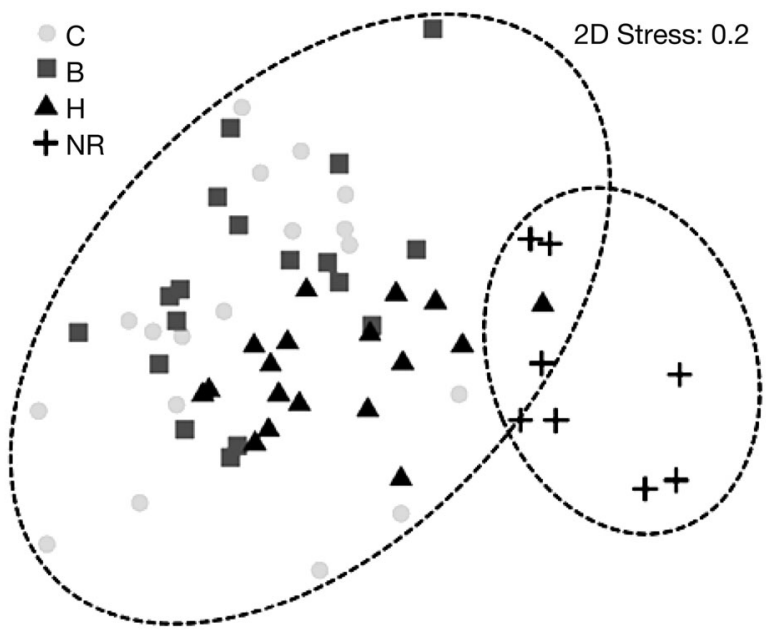

Fig. 6. MDS of community composition per habitat type $(\mathrm{C}=$ culvert, $\mathrm{B}=$ box-culvert, $\mathrm{H}=$ chaotic heap type reef, $\mathrm{NR}=$ natural reef), with a clear separation (symbolized by the dashed lines) between AR habitat types $(\mathrm{C}, \mathrm{B}, \mathrm{H})$ and $\mathrm{NR}$

tion of $B$. boops to the dissimilarity between fish communities can be explained by the shoaling behavior of this species (Harmelin 1987), since it was either present in large numbers or absent.

Differences in FD between the ARs and the NR appeared only through FDis. The higher functional dispersion of the ARs conveys a higher functional richness. Differences in FD can be explained by differences in functional trait combinations of less abundant species that are exclusively present at one of the reef types (AR or NR). Three species were exclusively present at the NR: zebra seabream Diplodus cervinus Lowe, 1838, blacktailed wrasse Symphodus melanocercus Risso, 1810, and axillary wrasse $S$. mediterraneus Linnaeus, 1758. The absence of the 2 Symphodus species at the ARs could be due to lower larval dispersal as a result of their benthic egg phase, or to their territorial behavior and very small daily movement ranges. Furthermore, both species lay their eggs on either algae or seaweed, which were uncommon on the studied ARs. Their absence could also be due to higher predation pressure at the ARs (Leitão et al. 2008, Ryan et al. 2012) acting on fish assemblages. In fact, out of the 11 species exclusively present at the ARs, some were carnivores or omnivores with diets that include small fishes, such as European seabass Dicentrarchus labrax Linnaeus, 1758, brown meagre Trachurus trachurus, Sciaena umbra Linnaeus, 1758, and forkbeard Phycis phycis Linnaeus, 1766. European conger Conger conger Linnaeus, 1758, was also present in very high densities at the ARs compared with the NR. Fishes only present at the ARs were generally demersal species with high daily movement ranges, such as Dicentrarchus labrax, gilthead seabream Sparus aurata Linnaeus, 1758, common pandora Pagellus erythrinus Linnaeus, 1758, axillary seabream Pagellus acarne Risso, 1827, which are likely transient species at the AR. These higher trophic level fishes may be attracted by the high food concentration at the ARs due to mussel cover and the aggregation of small foaging species such as Boops boops (B. Koeck \& P. Lenfant pers. obs.).

Differences between the fish communities of the ARs and the NR could also be due to different fishing pressures at these 2 locations. A survey of artisanal fishery landings conducted in 2012 along the French Catalan coast estimated the fishing effort at $6410 \mathrm{~m}$ of fishernet $\mathrm{km}^{-2}$ at Cape Leucate, and $1827 \mathrm{~m}$ of fishernet $\mathrm{km}^{-2}$ at the ARs of Leucate-Le Barcarès (A. Caro, R. Neveu, P. Lenfant unpubl. data). The high fishing pressure at Cape Leucate can be explained by the fact that it is the only rocky reef in the area, concentrating the fishing pressure. In contrast, the ARs from Leucate-Le Barcarès were only recently immersed, and their exact position was not disseminated - thereby reducing fishing pressure at these newly created habitats. Furthermore, as mentioned by local artisanal fishermen, the high structural complexity and short distances between the AR subsets prevents professional fishermen from deploying nets and long-lines too close to the reefs (i.e. inside the 6 reef groups), because doing so would place them at risk of losing their fishing gear (E. Berton pers. comm.). As fishing pressure can affect the speciesarea relationship (Tittensor et al. 2007), fish communities at Cape Leucate are most likely the result of decades of selective fishing pressure, which could explain the low densities and functional richness of the NR compared with the AR locations. For instance, Micheli \& Halpern (2005) observed that due to selective fishing in temperate reefs, fishes of higher trophic levels (such as carnivores) are underrepresented in fished areas compared with protected areas. The hypothesis that fishing pressure affects fish assemblages is also supported by our results. In fact, the primary contributing species to the observed dissimilarity of fish assemblages between reef types (i.e. Mullus sp., Trachurus trachurus, Diplodus sargus and $D$. vulgaris) are also species targeted by artisanal fisheries (Forcada et al. 2010). Moreover, fishes of higher trophic levels also targeted by artisanal fisheries (Griffiths et al. 2007) were encountered on the ARs (e.g. Dicentrarchus labrax, Phycis phycis, Sparus aurata, Sciaena umbra, and Pagellus acarne) but absent on the NR during our censuses (see Table 3 for species list). 


\section{Rapid AR colonization}

As no differences were observed in fish densities between the 2 AR locations (AR-Near and AR-Far) and among years, the fish assemblages appear to have colonized the ARs rapidly after their immersion (i.e. in less than $2 \mathrm{yr}$ ). The predominance of mediumsized adults across the surveyed years showed that the ARs were directly colonized by adult fish coming from other rocky reefs. No effect of distance to the NR was detected on fish assemblages, which could either mean that the colonization occurred in the first year after immersion and the AR fish communities had already stabilized, or that the colonization of the Leucate-Le Barcarès ARs was not related to the distance from Cape Leucate, the closest NR to the studied ARs. This second hypothesis is quite plausible as colonization is a complex process influenced by biological and physical factors, such as the dispersal of early life stages due to hydrologic conditions, the orientation mechanisms of larvae (Houde 2008), the movement capacity of adult fishes (Harmelin 1987, Vega Fernández et al. 2008) and the interactions among species (Leitão et al. 2008).

Nevertheless, a general decrease of species and functional evenness was observed between 2006 and 2009 for the AR locations. Inter-annual variations were also observed in the community composition of the ARs, whereas no inter-annual fluctuations were observed at the NRs. This difference could be explained by the aggregative behavior of particularly abundant fishes at the ARs such as Boops boops and Trachurus trachurus, which are notoriously shoaling species. Other highly abundant species such as Mullus sp., Diplodus sargus and D. vulgaris can also occur in some circumstances in wide shoals. Another explanation for the observed inter-annual fluctuations at the ARs could be that the studied ARs were only recently immersed, and as a result the fish assemblages had not yet stabilized. Benthos settlement studies have revealed that newly created hard substratum can be rapidly colonized, but take several years before reaching a community structure equilibrium (Fager 1971), with assemblages changing over time with increased reef maturity (Russell 1975, Bohnsack \& Sutherland 1985). However, previous temperate AR studies focusing on the first months of colonization have shown that fish densities and species richness rapidly reach a peak after deployment within a few months (Bohnsack \& Sutherland 1985, Bayle-Sempere et al. 1994, Bohnsack et al. 1994, Folpp et al. 2011). Long-term monitoring, such as a $10 \mathrm{yr}$ survey of fish assemblages associated with ARs in the Ligurian Sea (Italy), has revealed increases and decreases of some fish species (Relini et al. 2002). Further investigations would thus be necessary to monitor the temporal trends of fish assemblages and to study the effect of reef maturation.

\section{Effect of AR habitat complexity}

A higher fish density at ARs compared to NRs is often reported in the literature (Brickhill et al. 2005, Arena et al. 2007, Dupont 2008) and can most likely be explained by higher habitat heterogeneity, isolation and patchiness (Charbonnel et al. 2002, Gratwicke \& Speight 2005) as well as by increased niche partitioning at the ARs, which may also be the case in the present study. Besides the effect of differential fishing pressure, differences in habitat complexity and configuration could also have shaped fish assemblages and could explain the higher fish densities and functional diversity on the ARs compared to the NR. In fact, even if the habitat complexity has not been quantified in this study, it should be noted that the NR at Cape Leucate is a discontinuous rocky reef of nearly $1 \mathrm{~km}^{2}$, whereas an AR group covers only 0.012 ha and comprises several small discontinuous hard substratum reef subsets. Furthermore, several recognition dives and multi-beam sonar monitoring of the NR have shown the low complexity of this area (i.e. comprised of a rocky plateau with few anfractuosities and some rocky boulders of maximum $1 \mathrm{~m}$ height).

Among the ARs, differences in total fish densities and community composition were observed between the $\mathrm{H}$ reefs and the $\mathrm{B}$ and $\mathrm{C}$ reefs. No differences were observed between the $\mathrm{C}$ and $\mathrm{B}$ reefs. In fact, $\mathrm{C}$ and $\mathrm{B}$ reefs are small isolated reefs with relatively low complexity compared with the $\mathrm{H}$ reefs (see Fig. 2). Differences in the community composition between complex $(\mathrm{H})$ and less complex $(\mathrm{C}, \mathrm{B})$ artificial habitats can be explained by higher ecological niche partitioning due to habitat complexity, with the presence of crevices, caves and overhangs of different sizes. The significantly higher species diversity at the $\mathrm{H}$ reefs than the $\mathrm{C}$ reefs corroborates this idea.

Willis et al. (2005) showed that greater habitat complexity enhanced fish densities and influenced fish assemblage structures via increased niche partitioning in a neotropical floodplain river. In the Bay of Golfe Juan (Gulf of Lion, Mediterranean Sea), a similar result was reported (Charbonnel et al. 2002). An increase in the habitat complexity of existing $A R$ structures induced a 2 -fold increase of species rich- 
ness and a 10-fold increase of fish density (Charbonnel et al. 2002). According to Charbonnel et al. (2002), the increased habitat complexity would favor foraging opportunities and increase shelter availability for fishes. In another study, Gratwicke \& Speight (2005) simultaneously examined 5 habitat complexity variables: substrate rugosity, substrate diversity, variety of refuge hole size, height of substrate and percentage of hard substratum cover. Their results demonstrated that species diversity was most influenced by substrate rugosity, and fish density by hole size and percentage of hard substratum. Habitats with small hole sizes and rugose substrates would increase shelter and predator-free space, and thus support more fishes (Gratwicke \& Speight 2005).

In our case study, and contrary to the above mentioned examples in which higher densities were observed with increased complexity, total fish densities were higher at the less complex reefs $(B, C)$. The high densities at the low-complexity ARs could either be caused by inter-reef interaction (Bohnsack \& Sutherland 1985, Vega Fernández et al. 2008) due to the short distance $(50 \mathrm{~m})$ between each reef set within a reef group, or by the higher edge effect on the small ARs (higher ratio of the perimeter to the reef area; Bohnsack et al. 1994).

\section{Ecological and management implications for ARs}

Contrary to other existing fishing resource management tools such as fishing gear limitations, fishing quotas or protected areas, ARs induce a modification of the habitat, and therefore necessarily impact natural ecosystems. Depending on the opinions of the authors of case studies, ARs are either considered 'habitat alterations' with a negative connotation (Polovina 1989, Wilding 2006) or 'habitat enhancements' with a positive connotation (Hunter \& Sayer 2009, Santos et al. 2011). In fact, on the one hand the habitat modification engendered by the immersion of ARs could positively affect ecosystems by creating new, more complex habitats, enhancing species richness and abundance (Petchey 2003) and thus increasing ecosystem resilience and stability in the face of disturbances that are more and more likely to occur in today's context of global change (Vitousek et al. 1997). According to Nyström et al. (2008), a high diversity of habitat types ensures the representation of a wide range of functional traits within coral reef seascapes. On the other hand, ARs could negatively impact ecosystems by disturbing the existing equilibrium or ecological interactions and thus funda- mental ecological processes (Wilding 2006, Leitão 2013). For example, the replacement of sandy bottom habitat by hard bottom habitat may destroy essential juvenile habitat (Polovina 1989). In the context of coral ecosystems, Nyström et al. (2008) also highlight in their review the dual role of increased connectivity between habitat patches. Increased connectivity would facilitate the dispersion of contagious disturbances such as invasive species or pathogens, which could also be a potential risk of ARs, as they increase the connectivity between distant NRs.

The main debate around ARs, however, has long been whether they act to simply attract and aggregate fishes by delocalizing them from NRs, or produce additional biomass by providing new shelter and food possibilities for fishes in a resource-limited system (Pickering \& Whitmarsh 1997). The long-term threat inherent in the attraction hypothesis is that ARs would concentrate fishes in small areas, enhancing the access of fishermen to fishes and thus increasing the overexploitation of fish stocks (Polovina 1989, Grossman et al. 1997). Following Osenberg et al. (2002), fish assemblages associated with the ARs from LeucateLe Barcarès are most likely the result of both mechanisms; i.e. the attraction of adult fishes from other hard substratum areas (rapid colonization by adult fishes) and the production of new biomass due to provision of new shelter and food opportunities (densities on $\mathrm{AR}>$ densities on NR; FD on AR > FD on NR).

Beyond the focused fisheries question (but in the scope of sustainable fisheries and conservation), it seems important to understand how ARs and their assemblages function compared with neighboring natural habitats, and which ecological roles they play as part of a coastal seascape via the assessment of the functional structure of fish communities. Even if predicting the long-term effects of these newly added habitats on coastal ecosystem processes is difficult, the present results indicate that fish assemblages of Leucate-Le Barcarès ARs are functionally different from those of natural rocky reefs, which could have potential effects on ecosystem functioning. These differences can likely be attributed to a higher habitat complexity (and niche partitioning; Nyström et al. 2008) and low fishing pressure (absence of selective extraction of fishes belonging to some specific functional niches; Mouillot et al. 2013b) at the ARs compared with the NR. These results are contrary to some previous studies in which no differences were found in the functional structure of fish assemblages belonging to ARs and NRs (Recasens et al. 2006, Santos \& Monteiro 2007), thus concluding that the equilibrium of fish assemblages was not disturbed by the 
ARs. In contrast to these studies in which the comparisons were based either on only one functional trait (Santos \& Monteiro 2007) or on morphological measurements (expressing morphological diversity; Recasens et al. 2006), our study included the comparison of different functional traits through multidimensional FD analysis, which could explain these different results. Furthermore, recent studies have shown that the investigation of the functional structure of communities using multidimensional FD indices is a suitable framework to detect different types of disturbances at an early stage (e.g. human impacts, biotic pressures and environmental changes), whereas traditional community descriptors (e.g. abundance and species diversity indices) are often poor indicators (Mouillot et al. 2013b). In fact, the analysis of functional groups permits the identification of changes in ecosystems before species loss occurs, and helps researchers to recognize cryptic losses of resilience (Nyström 2006, Mouillot et al. 2013b). Thus, given the growing knowledge of fish biology and ecology and databases such as FishBase (Froese \& Pauly 2012) available today, it is both easy and appropriate to use FD indices in future AR studies for the comparison of fish assemblages.

Acknowledgements. Funding for the UVC survey was provided by the European Union through the European grant for fisheries (FEP funds), the SIVOM Leucate-Le Barcarès, the regional council of Languedoc-Roussillon and the department of Aude. This work was in partial fulfilment of the doctoral thesis of B.K. at the EPHE (Paris), supported by a doctoral scholarship from the French Ministry of Higher Education and Research. Many thanks to Anthony Caro and Reda Neveu for providing information of fish catches on the study location. We also thank the anonymous reviewers for spending time to revise the manuscript and for their helpful comments.

\section{LITERATURE CITED}

Abecasis D, Erzini K (2008) Site fidelity and movements of gilthead sea bream (Sparus aurata) in a coastal lagoon (Ria Formosa, Portugal). Estuar Coast Shelf Sci 79: 758-763

> Abecasis D, Bentes L, Erzini K (2009) Home range, residency and movements of Diplodus sargus and Diplodus vulgaris in a coastal lagoon: connectivity between nursery and adult habitats. Estuar Coast Shelf Sci 85:525-529

Abecasis D, Bentes L, Erzini K (2012) Movements of Sarpa salpa (Linnaeus, 1758) (Sparidae) in a coastal lagoon (Ria Formosa, Portugal). J Appl Ichthyol 28:126-129

Abelson A (2006) Artificial reefs vs. coral transplantation as restoration tools for mitigating coral reef deterioration: benefits, concerns, and proposed guidelines. Bull Mar Sci 78:151-159

- Ackerman JL, Bellwood DR (2002) Comparative efficiency of clove oil and rotenone for sampling tropical reef fish assemblages. J Fish Biol 60:893-901

Alonso-Fernández A, Domínguez-Petit R, Bao M, Rivas C, Saborido-Rey F (2008) Spawning pattern and reproductive strategy of female pouting Trisopterus luscus (Gadidae) on the Galician shelf of north-western Spain. Aquat Living Resour 21:383-393

Alós J, Cabanellas-Reboredo M (2012) Experimental acoustic telemetry experiment reveals strong site fidelity during the sexual resting period of wild brown meagre, Sciaena umbra. J Appl Ichthyol 28:606-611

Alós J, March D, Palmer M, Grau A, Morales-Nin B (2011) Spatial and temporal patterns in Serranus cabrilla habitat use in the NW Mediterranean revealed by acoustic telemetry. Mar Ecol Prog Ser 427:173-186

- Alós J, Cabanellas-Reboredo M, March D (2012) Spatial and temporal patterns in the movement of adult two-banded sea bream Diplodus vulgaris (Saint-Hilaire, 1817). Fish Res 115-116:82-88

Anderson MJ, Robinson J (2003) Generalized discriminant analysis based on distances. Aust N Z J Stat 45:301-318

Anderson TW, Demartini EE, Roberts DA (1989) The relationship between habitat structure, body size and distribution of fishes at a temperate artificial reef. Bull Mar Sci 44:681-697

Angel DL, Spanier E (2002) An application of artificial reefs to reduce organic enrichment caused by net-cage fish farming: preliminary results. ICES J Mar Sci 59 (Suppl): S324-S329

Antsulevich AE (1994) Artificial reefs project for improvement of water quality and environmental enhancement of Neva Bay (St. Petersburg County Region). Bull Mar Sci 55:1189-1192

> Arena PT, Jordan LKB, Spieler RE (2007) Fish assemblages on sunken vessels and natural reefs in southeast Florida, USA. Hydrobiologia 580:157-171

Baine M, Side J (2003) Habitat modification and manipulation as a management tool. Rev Fish Biol Fish 13:187-199

Bayle-Sempere JT, Ramos-Espla AA, Charton JAG (1994) Intra-annual variability of an artificial reef fish assemblage in the marine reserve of Tabarca (Alicante, Spain, SW Mediterranean). Bull Mar Sci 55:824-835

Bohnsack JA, Sutherland DL (1985) Artificial reef research: a review with recommendations for future priorities. Bull Mar Sci 37:11-39

Bohnsack JA, Harper DE, McClellan DB, Hulsbeck M (1994) Effects of reef size on colonization and assemblage structure of fishes at artificial reefs off southeastern Florida, USA. Bull Mar Sci 55:796-823

Bosc E, Bricaud A, Antoine D (2004) Seasonal and interannual variability in algal biomass and primary production in the Mediterranean Sea, as derived from 4 years of SeaWiFS observations. Global Biogeochem Cycles 18:GB1005

> Bozec YM, Kulbicki M, Laloe F, Mou-Tham G, Gascuel D (2011) Factors affecting the detection distances of reef fish: implications for visual counts. Mar Biol 158:969-981

Brickhill MJ, Lee SY, Connolly RM (2005) Fishes associated with artificial reefs: attributing changes to attraction or production using novel approaches. J Fish Biol 67:53-71

Brind'Amour A, Rouyer A, Martin J (2009) Functional gains of including non-commercial epibenthic taxa in coastal beam trawl surveys: a note. Cont Shelf Res 29:1189-1194

Burchmore JJ, Pollard DA, Bell JD, Middleton MJ, Pease BC, Matthews J (1985) An ecological comparison of artificial and natural rocky reef fish communities in Botany Bay, New South Wales, Australia. Bull Mar Sci 37:70-85 
Burke L, Kura Y, Kasem K, Revenga C, Spalding M, McAllister D (2001) Coastal ecosystems. World Resources Institute, Washington, DC

Cetinic P, Skeljo F, Ferri J (2011) Discards of the commercial boat seine fisheries on Posidonia oceanica beds in the eastern Adriatic Sea. Sci Mar 75:289-300

Chakroun-Marzouk N, Ktari MH (2006) Caractéristiques de la reproduction et de la croissance pondérale relative de Pomadasys incisus (Pisces, Haemulidae) du golfe de Tunis. Cybium 30:333-342

Chaoui L, Kara MH, Faure E, Quignard JP (2006) Growth and reproduction of the gilthead seabream Sparus aurata in Mellah lagoon (north-eastern Algeria). Sci Mar 70: 545-552

Charbonnel E, Serre C, Ruitton S, Harmelin JG, Jensen A (2002) Effects of increased habitat complexity on fish assemblages associated with large artificial reef units (French Mediterranean coast). ICES J Mar Sci 59 (Suppl):S208-S213

Clarke KR, Warwick RM (2001) Change in marine communities: an approach to statistical analysis and interpretation. Plymouth Marine Laboratory, Plymouth

Cole J (2005) Communication between terrestrial and marine ecologists: loud, sometimes abrasive, but healthy and occasionally useful. Mar Ecol Prog Ser 304:272-274

Colwell RK (2006) EstimateS: statistical estimation of species richness and shared species from samples (software and user's guide), Version 8. http://viceroy.eeb.uconn.edu/ estimates

Curran S, Kumar A, Lutz W, Williams M (2002) Interactions between coastal and marine ecosystems and human population systems: perspectives on how consumption mediates this interaction. Ambio 31:264-268

D'Anna G, Giacalone VM, Pipitone C, Badalamenti F (2011) Movement pattern of white seabream, Diplodus sargus (L., 1758) (Osteichthyes, Sparidae) acoustically tracked in an artificial reef area. Ital J Zool 78:255-263

> Depczynski M, Bellwood DR (2003) The role of cryptobenthic reef fishes in coral reef trophodynamics. Mar Ecol Prog Ser 256:183-191

Derbal F, Kara MH (2006) Régime alimentaire du sar tambour, Diplodus cervinus cervinus (Sparidae) des côtes de l'est algérien. Cybium 30:161-170

- Dupont JM (2008) Artificial reefs as restoration tools: a case study on the west Florida shelf. Coast Manag 36: 495-507

Fager EW (1971) Pattern in the development of a marine community. Limnol Oceanogr 16:241-253

Fehri-Bedoui R, Gharbi H (2008) Sex-ratio, reproduction and feeding habits of Pomadasys incisus (Haemulidae) in the Gulf of Tunis (Tunisia). Acta Adriat 49:5-18

Folpp H, Lowry M, Gregson M, Suthers IM (2011) Colonization and community development of fish assemblages associated with estuarine artificial reefs. Braz J Oceanogr 59:55-67

- Forcada A, Valle C, Sánchez-Lizaso JL, Bayle-Sempere JT, Corsi F (2010) Structure and spatio-temporal dynamics of artisanal fisheries around a Mediterranean marine protected area. ICES J Mar Sci 67:191-203

Froese R, Pauly D (eds) (2012) FishBase. www.fishbase.org

> Gao QF, Shin PKS, Xu WZ, Cheung SG (2008) Amelioration of marine farming impact on the benthic environment using artificial reefs as biofilters. Mar Pollut Bull 57: 652-661

García-Charton JA, Pérez-Ruzafa Á (2001) Spatial pattern and the habitat structure of a Mediterranean rocky reef fish local assemblage. Mar Biol 138:917-934

- Gratwicke B, Speight MR (2005) Effects of habitat complexity on Caribbean marine fish assemblages. Mar Ecol Prog Ser 292:301-310

Griffiths RC, Robles R, Coppola SR, Camiñas JA (2007) Is there a future for artisanal fisheries in the western Mediterranean? FAO, Rome

Grossman GD, Jones GP, Seaman WJ (1997) Do artificial reefs increase regional fish production? A review of existing data. Fisheries 22:17-23

Harmelin JG (1987) Structure and variability of the ichtyofauna in a Mediterranean protected rocky area (national park of Port-Cros, France). Mar Ecol 8:263-284

Harmelin-Vivien M, Harmelin J (1975) Présentation d'une méthode d'évaluation in situ de la faune ichtyologique. Trav Sc PN Port-Cros 1:47-52

Harmelin-Vivien M, Harmelin JG, Chauvet C, Duval C and others (1985) Evaluation visuelle des peuplements et populations de poissons: problèmes et méthodes. Rev Ecol Terre Vie 40:467-539

$>$ Hooper DU, Chapin FS, Ewel JJ, Hector A and others (2005) Effects of biodiversity on ecosystem functioning: a consensus of current knowledge. Ecol Monogr 75:3-35

Houde (2008) Emerging from Hjort's shadow. J Northwest Atl Fish Sci 41:53-70

Hunter WR, Sayer MDJ (2009) The comparative effects of habitat complexity on faunal assemblages of northern temperate artificial and natural reefs. ICES J Mar Sci 66: 691-698

Jackson JBC (2008) Ecological extinction and evolution in the brave new ocean. Proc Natl Acad Sci USA 105: 11458-11465

Jadot C, Donnay A, Acolas ML, Cornet Y, Anras MLB (2006) Activity patterns, home-range size, and habitat utilization of Sarpa salpa (Teleostei: Sparidae) in the Mediterranean Sea. ICES J Mar Sci 63:128-139

Jensen A, Collins KJ, Lockwood APM (2000) Current issues relating to artificial reefs in European seas. In: Jensen A, Collins KJ, Lockwood APM (eds) Artificial reefs in European seas. Kluwer Academic Publishers, Dordrecht

Koeck B, Pastor J, Larenie L, Astruch P, Saragoni G, Jarraya M, Lenfant P (2011) Evaluation of impact of artificial reefs on artisanal fisheries: need for complementary approaches. Braz J Oceanogr 59:1-11

Koeck B, Alós J, Caro A, Neveu R, Crec'hriou R, Saragoni G, Lenfant P (2013) Contrasting fish behavior in artificial seascapes with implications for resources conservation. PLoS ONE 8:e69303

> La Mesa M, Colella S, Giannetti G, Arneri E (2008) Age and growth of brown meagre Sciaena umbra (Sciaenidae) in the Adriatic Sea. Aquat Living Resour 21:153-161

$>$ Labropoulou M, Tserpes G, Tsimenides N (1998) Age, growth and feeding habits of the brown comber Serranus hepatus (Linnaeus, 1758) on the Cretan shelf. Estuar Coast Shelf Sci 46:723-732

Laliberté E, Legendre P (2010) A distance-based framework for measuring functional diversity from multiple traits. Ecology 91:299-305

Leihonen P, Hanninen J, Chojnacki J, Vuorinen I (1996) Some prospects of nutrients removal with artificial reefs. In: Jensen AC (ed) Proc First Eur Artif Reef Res Netw Conf. Southampton Oceanographic Center, Southampton

Leitão F (2013) Artificial reefs: from ecological processes to fishing enhancement tools. Braz J Oceanogr 61:77-81 
Leitão F, Santos MN, Erzini K, Monteiro CC (2008) The effect of predation on artificial reef juvenile demersal fish species. Mar Biol 153:1233-1244

Lyashevska O, Farnsworth KD (2012) How many dimensions of biodiversity do we need? Ecol Indic 18:485-492

Machias A, Somarakis S, Tsimenides N (1998) Bathymetric distribution and movements of red mullet Mullus surmuletus. Mar Ecol Prog Ser 166:247-257

MacNeil MA, Tyler EHM, Fonnesbeck CJ, Rushton SP, Polunin NVC, Conroy MJ (2008) Accounting for detectability in reef-fish biodiversity estimates. Mar Ecol Prog Ser 367:249-260

> March D, Alós J, Grau A, Palmer M (2011) Short-term residence and movement patterns of the annular seabream Diplodus annularis in a temperate marine reserve. Estuar Coast Shelf Sci 92:581-587

Margalef R (1958) Information theory in ecology. Gen Syst 3: $36-71$

> Markle DF (1982) Identification of larval and juvenile Canadian Atlantic gadoids with comments on the systematics of gadid subfamilies. Can J Zool 60:3420-3438

Méndez-Villamil M, Pajuelo JG, Lorenzo JM, Coca J, Ramos AG (2001) Age and growth of the salema, Sarpa salpa (Osteichthyes, Sparidae), off the Canary Islands (Eastcentral Atlantic). Arch Fish Mar Res 49:139-148

Micheli F, Halpern BS (2005) Low functional redundancy in coastal marine assemblages. Ecol Lett 8:391-400

> Mouillot D, Bellwood DR, Baraloto C, Chave J and others (2013a) Rare species support vulnerable functions in high-diversity ecosystems. PLoS Biol 11:e1001569

> Mouillot D, Graham NAJ, Villéger S, Mason NWH, Bellwood DR (2013b) A functional approach reveals community responses to disturbances. Trends Ecol Evol 28: 167-177

> Nicoletti L, Marzialetti S, Paganelli D, Ardizzone GD (2007) Long-term changes in a benthic assemblage associated with artificial reefs. Hydrobiologia 580:233-240

> Nyström M (2006) Redundancy and response diversity of functional groups: implications for the resilience of coral reefs. Ambio 35:30-35

> Nyström M, Graham NAJ, Lokrantz J, Norström AV (2008) Capturing the cornerstones of coral reef resilience: linking theory to practice. Coral Reefs 27:795-809

Osenberg CW, St. Mary CM, Wilson JA, Lindberg WJ (2002) A quantitative framework to evaluate the attractionproduction controversy. ICES J Mar Sci 59 (Suppl): S214-S221

> Palmer M, Balle S, March D, Alós J, Linde M (2011) Size estimation of circular home range from fish markrelease-(single)-recapture data: case study of a small labrid targeted by recreational fishing. Mar Ecol Prog Ser 430:87-146

$>$ Petchey OL (2003) Integrating methods that investigate how complementarity influences ecosystem functioning. Oikos 101:323-330

> Pickering H, Whitmarsh D (1997) Artificial reefs and fisheries exploitation: a review of the 'attraction versus production' debate, the influence of design and its significance for policy. Fish Res 31:39-59

> Pickering H, Whitmarsh D, Jensen A (1999) Artificial reefs as a tool to aid rehabilitation of coastal ecosystems: investigating the potential. Mar Pollut Bull 37:505-514

$>$ Pielou EC (1966) The measurement of diversity in different types of biological collections. J Theor Biol 13:131-144

Pita P, Freire J (2011) Movements of three large coastal predatory fishes in the northeast Atlantic: a preliminary telemetry study. Sci Mar 75:759-769

Polovina JJ (1989) Artificial reefs: nothing more than benthic fish aggregators. Calif Coop Ocean Fish Invest Rep 30:37-39

R Development Core Team (2012) R: a language and environment for statistical computing. R Foundation for Statistical Computing, Vienna

Recasens L, Lombarte A, Sanchez P (2006) Teleostean fish assemblages in an artificial reef and a natural rocky area in Catalonia (northwestern Mediterranean): an ecomorphological approach. Bull Mar Sci 78:71-82

Reed DC, Schroeter SC, Huang D, Anderson TW, Ambrose RF (2006) Quantitative assessment of different artificial reef designs in mitigating losses to kelp forest fishes. Bull Mar Sci 78:133-150

Relini G, Relini M, Torchia G, Palandri G (2002) Ten years of censuses of fish fauna on the Loano artificial reef. ICES J Mar Sci 59:S132-S137

Relini G, Fabi G, dos Santos MN, Moreno I, Charbonnel E (2008) Fisheries and their management using artificial reefs in the northwestern Mediterranean Sea and southern Portugal. In: Nielsen J, Dodson JJ, Friedland K, Hamon TR, Musick J, Verspoor E (eds) Reconciling Fisheries with Conservation, Vols I and II. American Fisheries Society Symposium No. 49, Bethesda, MD

$>$ Reubens JT, Degraer S, Vincx M (2011) Aggregation and feeding behaviour of pouting (Trisopterus luscus) at wind turbines in the Belgian part of the North Sea. Fish Res 108:223-227

Rogdakis Y, Ramfos A, Koukou K, Dimitriou E, Katselis G (2010) Feeding habits and trophic level of sea bass (Dicentrarchus labrax) in the Messolonghi-Etoliko lagoons complex (Western Greece). J Biol Res 13:13-26

Russell BC (1975) The development and dynamics of a small artificial reef community. Helgol Wiss Meeresunters 27: 298-312

> Ryan MR, Killen SS, Gregory RS, Snelgrove PVR (2012) Predators and distance between habitat patches modify gap crossing behaviour of juvenile Atlantic cod (Gadus morhua, L. 1758). J Exp Mar Biol Ecol 422-423:81-87

Santos MN, Monteiro CC (1998) Comparison of the catch and fishing yield from an artificial reef system and neighbouring areas off Faro (Algarve, south Portugal). Fish Res 39:55-65

> Santos MN, Monteiro CC (2007) A fourteen-year overview of the fish assemblages and yield of the two oldest Algarve artificial reefs (southern Portugal). Hydrobiologia 580:225-231

Santos LN, Garcia-Berthou E, Agostinho AA, Latini JD (2011) Fish colonization of artificial reefs in a large Neotropical reservoir: material type and successional changes. Ecol Appl 21:251-262

Scarcella G, Grati F, Polidori P, Domenichetti F, Bolognini L, Fabi G (2011a) Comparison of growth rates estimated by otolith reading of Scorpaena porcus and Scorpaena notata caught on artificial and natural reefs of the northern Adriatic sea. Braz J Oceanogr 59:33-42

Scarcella G, La Mesa M, Grati F, Polidori P (2011b) Age and growth of the small red scorpionfish, Scorpaena notata Rafinesque, 1810, based on whole and sectioned otolith readings. Environ Biol Fishes 91:369-378

Seaman WJ, Jensen AC (2000) Purposes and practices of artificial reef evaluation. In: Seaman WJ (ed) Artificial reef evaluation: with application to natural marine habitats. CRC Press, Boca Raton, FL 
Stergiou KI, Karpouzi VS (2001) Feeding habits and trophic levels of Mediterranean fish. Rev Fish Biol Fish 11: 217-254

Tilman D (2004) Niche tradeoffs, neutrality, and community structure: a stochastic theory of resource competition, invasion, and community assembly. Proc Natl Acad Sci USA 101:10854-10861

Tittensor DP, Micheli F, Nystrom M, Worm B (2007) Human impacts on the species-area relationship reef fish assemblages. Ecol Lett 10:760-772

Tsemel A, Spanier E, Angel DL (2006) Benthic communities of artificial structures: effects of mariculture in the Gulf of Aqaba (Eilat) on development and bioaccumulation. Bull Mar Sci 78:103-113

Tzanatos E, Somarakis S, Tserpes G, Koutsikopoulos C (2008) Catch length analysis, relation to minimum landing sizes and management implications from a Mediterranean small-scale fishery (Patraikos Gulf, Greece). Fish Res 93:125-134

UNEP (2006) Marine and coastal ecosystems \& human wellbeing: a synthesis report based on the findings of the Millenium Ecosystem Assessment. United Nations Environment Programme, Nairobi

Vega Fernández T, D’Anna G, Badalamenti F, Pérez-Ruzafa

Editorial responsibility: Paul Sammarco,

Chauvin, Louisiana, USA
A (2008) Habitat connectivity as a factor affecting fish assemblages in temperate reefs. Aquat Biol 1:239-248

- Villéger S, Mason NWH, Mouillot D (2008) New multidimensional functional diversity indices for a multifaceted framework in functional ecology. Ecology 89:2290-2301

Vinagre C, Santos FD, Cabral H, Costa MJ (2011) Impact of climate warming upon the fish assemblages of the Portuguese coast under different scenarios. Reg Environ Change 11:779-789

Vitousek PM, Mooney HA, Lubchenco J, Melillo JM (1997) Human domination of Earth's ecosystems. Science 277: 494-499

Wilding TA (2006) The benthic impacts of the Loch Linnhe artificial reef. Hydrobiologia 555:345-353

Willis TJ (2001) Visual census methods underestimate density and diversity of cryptic reef fishes. J Fish Biol 59: 1408-1411

Willis SC, Winemiller KO, Lopez-Fernandez H (2005) Habitat structural complexity and morphological diversity of fish assemblages in a Neotropical floodplain river. Oecologia 142:284-295

> Worm B, Barbier EB, Beaumont N, Duffy JE and others (2006) Impacts of biodiversity loss on ocean ecosystem services. Science 314:787-790

Submitted: April 22, 2013; Accepted: February 13, 2014

Proofs received from author(s): April 3, 2014 